\title{
Expert System Diagnose Disease in Poultry Using Certainty Factor Method
}

\author{
Oktavio Nansia ${ }^{1}$, Bosker Sinaga ${ }^{2}$ \\ 1,2 Informatics Engineering Study Program, STMIK Pelita Nusantara, Jl. St. Iskandar Muda No. 1. \\ Medan, North Sumatara, Indonesia 20154 \\ E-mail: oktavionansia7@gmail.com,sinagab8@gmail.com
}

\begin{abstract}
Abstrack-In this study, the authors conducted research to apply the Certainty Factor Method to Diagnose Diseases in Livestock and build applications in the application of Reviews These methods. Information technology is now a staple in developing a field. Along with the development of the times, proper information management is needed, so we need an Appropriate computational method. In this case the expert system method is one way to find out or identify diseases in poultry that have been infected with bacteria or viruses. A form of management information system specifically created to support a plan in making decisions to solve a case or problem. Artificial Intelligence (Artifical Intelligence) is one part of computer science that makes machines (computers) can do work as and as well as humans do. Expert System is one of the Artificial Intelligence techniques that attempts to adopt human knowledge into computers, so that computers can solve problems as is usually done by experts. Diagnosing disease in poultry is currently a problem that is still underestimated for most people, this is due to lack of knowledge or lack of information in terms of Overcoming and Preventing Contaminated, viruses or bacteria. Certainty Theory Theory was suggested by Shortlife and Buchanan in 1975 to a accommodate the uncertainty of thinking or inexact reasoning of an expert. Phrases like "maybe", "most likely", "almost Certain". To a accommodate this, Researchers conducted a certainty factor method to describe the level of expert confidence in problems in diseases Suffered by chickens already infected with dangerous viruses.
\end{abstract}

Keywords: Expert System, the Certainty Factors, Disease, Livestock Chickens

\section{Introduction}

Current information technology become essential in the development field. As time management right information is necessary, so that it takes an appropriate computational methods. In this case the expert system method to be one way to find or identify the disease in chickens that had been infected with the bacteria or virus. A form of the Management of the information systems that are specifically designed to support a plan in the decision to settle a case or problem. The technology is closely related to Artificial Intelligence today is how humans create technology that is able to think like the man himself,

Artificial Intelligence (Artifical Intelligence) is one part of computer science that make the machine (computer) can do the job and is as good as done by humans. Artificial intelligence is also an information system related to the capture, modeling and storage of human intelligence in an information technology system so that the system has the intelligence of a human being who has. The system was developed to develop methods and systems to solve the problem, usually solved through human intellectual activity, eg image processing, design, forecasting and others, improve the performance of computer-based information systems.

Expert System is one of the techniques of Artificial Intelligence are trying to adopt human knowledge into a computer so that the computer can resolve the issue as was done by experts. Expert System is designed to solve a particular problem by mimicking the work of experts. With a human expert system able to resolve the actual problem can only be solved with the help of experts only. For experts, the expert system will also help activities as asistem very experienced.

According to various experts on the expert system is, according Durkin expert system is a computer program designed to model problem-solving ability is what an expert. According Ignizio expert system is a model and procedures relating, in a particular domain, where the level of expertise that can be compared to an individual's expertise expert. According to Riley Giarratano and expert system is a computer system that could match or mimic the ability of an expert.

Diagnose diseases in animals chickens now become a problem that is still vastly underestimated for most people, this is still lack of knowledge or lack of information in terms of address and prevent viruses or bacteria that have been contaminated. In addition the ratio between the number of people or poultry breeders, and limited facilities for consulting services is the key factor, and also the high cost incurred when farmers want to do the inspection process will be an obstacle for farmers. 
Certainty Factor theory suggested by shortllife and Buchanan in 1975 to accommodate the uncertainty of thought or (inexact reasoning) an expert. Phrases such as "may", "likely", "almost certainly". To accommodate this case the researchers carried out using a method to describe the certainty factor confidence level experts on the problem on diseases suffered by chickens that had been infected with dangerous viruses.

Pests and diseases of livestock since 2003 the disease has spread from birds in Asia to the Middle East, Europe and Africa. In some cases, people can also get the disease, generally Due to related or lagsung contact with infected birds. Until recently bird flu cases in humans worldwide, and many of them died. In Indonesia bird flu cases in humans were first reported in 2005. Since then, Indonesia has recorded more than 130 cases burng flu in humans and more than 110 deaths. This case is the highest bird flu victim in Indonesia, children are one of the groups most at risk of this disease since approximately $40 \%$ of victims of bird flu are those aged under 18 years.

\section{Theory}

\section{A. Expert system}

The expert system is a system that uses human knowledge where knowledge is inserted into a computer and then used to solve problems that require expertise or human expertise (Turban-2001). Computer programs are presented and reasoning with some expert knowledge to solve problems or give advice (Jackson 1999). Knowledge-based programs that provide "quality experts" to the problems in the field (domain) specific (Luger \& Stubbefield-1993).

\section{B. Method of Certainty Factor}

Inference method is a way of inference performed by the inference engine in resolving the problem. Factors Ceratinty method is a method to prove whether a fact that certainly would not have been shaped or metric that is usually digunakkan in expert systems.

One theory could be used to solve the problem of uncertainty which will be discussed in this book is Kepastastian Factor Theory (Certainty Factor). This theory was introduced by Shorliffe Buchanan in the manufacture of an expert system, which owns MYCIN clinical parameter values given MYCIN to show great confidence. CF shows the size of the certainty of the fact or rule, the highest value in the CF is +1.0 (definitely correct or Definitely), and the lowest value in the CF is -1.0 (Surely one or Definitely not). A positive value presented some degree of confidence, while a negative value present degree of uncertainty. Certainty Factor is defined as follows:

$$
\mathrm{CF}[\mathrm{h}, \mathrm{e}]=\mathrm{MB}[\mathrm{h}, \mathrm{e}]-\mathrm{MD}[\mathrm{h}, \mathrm{e}]
$$

Information :

$\mathrm{CF}[\mathrm{h}, \mathrm{e}] \quad=$ Certainty Factor

$\operatorname{MB}[\mathrm{h}, \mathrm{e}] \quad=$ Size of trust / confidence level of the hypothesis $\mathrm{h}$, if given / influenced by evidence e (between 0 and 1 ).

$\mathrm{MD}[\mathrm{h}, \mathrm{e}]=$ Uncertainty of the size / level of uncertainty of the hypothesis $\mathrm{h}$, if given / influenced by evidence e (between 0 and 1).

\section{Analysis}

In This calculation there are 3 things that might happen on Certainty Factor.

1) Some evidence combined to determine the CF of a hypothesis. If e 1 and e 2 are observation, then:

$$
\begin{aligned}
& \mathrm{MB}\left[\mathrm{h}, e_{1} \nabla e_{2}\right]=\left\{\frac{0}{\mathrm{MB}\left[\mathrm{h}, e_{1}\right]+\mathrm{MB}\left[\mathrm{h}, e_{2}\right] \cdot\left(1-\mathrm{MB}\left[\mathrm{h}, e_{1}\right]\right)}\right. \\
& \mathrm{MD}\left[\mathrm{h}, e_{1} \otimes e_{2}\right]=\left\{\frac{0}{\mathrm{MD}\left[\mathrm{h}, e_{1}\right]+\mathrm{MD}\left[\mathrm{h}, e_{2}\right] \cdot\left(1-\mathrm{MD}\left[\mathrm{h}, e_{1}\right]\right)}\right.
\end{aligned}
$$

2) Certainty Factor of a combination of several hypotheses. If $\mathrm{h} 1$ and $\mathrm{h} 2$ is a hypothesis, then: 


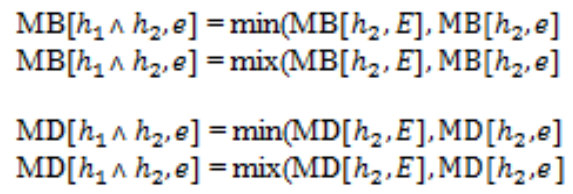

Some rules were hand in hand, the uncertainty of a rule becomes the input for other rules, then:

\section{Conclusion}

Of the subject matter that has been discussed before, DAPT be concluded as follows: "To build build an expert system to diagnose the disease in chickens using certainty factor adaalah first authors performed an analysis calculations using the methods certainty factor, needs analysis system, perform calculations certainty factor method, system design with UML, the database design, user interface design, and web-based systems pembangaunan.

\section{Reference}

[1] Anhar. 2010. Panduan Menguasai PHP \& MySQL Secara Otodidak Jakarta:Mediakita.

[2] Edgar Winata, Johan Setiawan. Analisis Perancangan Prototipe Aplikasi Tracking Bis Universitas Multimedia Nusantara pada Platform Android. ULTIMA InfoSys, 2013, 4 (1), 35-37.

[3] Haviluddin. Memahami Penggunaan UML (Unified Modeling Language). Jurnal Informatika Mulawarman, 2011, 6 (1), 1-7.

[4] Rika Rosnelly, Inunk Nastiti. 2012. Sistem Pakar Konsep dan Teori. Yogyakarta: CV Andi Offset.

[5] Sutanta. Benedicta Rini W. 2011. Basis Data Dalam Tinjauan

[6] Konseptual.Yogyakarta: CV Andi Offset.

[7] T.Sutojo,Edy Mulyanto Dr,Vincent Suhartono. Benedicta Rini W.2011. Kecerdasan Buatan. Yogyakarta: CV Andi Offset.

[8] Donald A.Waterman. 1986.A Guide to Expert System. Newyork: The Rand Corporation3

[9] Jack Challoner, 2012. Kecerdasan Artifical. Jakarta: Erlangga. 